\title{
Oxidative stress biomarkers in different tissues of rainbow trout (Oncorhynchus mykiss) exposed to Disinfectant-CIP formulated with peracetic acid and hydrogen peroxide
}

\author{
Halyna Tkachenko, Natalia Kurhaluk, Joanna Grudniewska
}

Received - 19 September 2013/Accepted - 04 July 2014. Published online: 30 September 2014; @Inland Fisheries Institute in Olsztyn, Poland Citation: Tkachenko H., Kurhaluk N., Grudniewska J. 2014 - Oxidative stress biomarkers in different tissues of rainbow trout (Oncorhynchus mykiss) exposed to Disinfectant-CIP formulated with peracetic acid and hydrogen peroxide - Arch. Pol. Fish. 22: $207-219$.

\begin{abstract}
The aim of study was to determine the effects of exposure to the product DEZYNFEKTANT-CIP (Eng. Disinfectant-CIP), which is formulated with peracetic acid and hydrogen peroxide, on oxidative stress biomarkers (lipid peroxidation (LPO) levels and the carbonyl content of oxidatively modified proteins) and antioxidant defenses (superoxide dismutase (SOD), catalase (CAT), glutathione reductase (GR), glutathione peroxidase (GPx), total antioxidant capacity) in muscle, gill, hepatic, and cardiac tissues of rainbow trout, Oncorhynchus mykiss (Walbaum). LPO and carbonyl contents changed with tissue type. Exposure to Disinfectant-CIP led to a significant decrease in LPO in muscle tissues and carbonyl content in muscle and gill tissues. The inhibition of SOD and CAT activity in muscle, hepatic, and cardiac tissues was observed probably because of increased oxidative stress during disinfection; however, hepatic and cardiac GPx activity increased in an attempt to counteract oxidative stress. We suggest that oxidative stress during the oxidation of peracetic acid and hydrogen peroxide could be counteracted by the antioxidant system in trout
\end{abstract}

\footnotetext{
H. Tkachenko [ڤ], N. Kurhaluk

Department of Zoology and Animal Physiology

Institute of Biology and Environmental Protection

Pomeranian University, Słupsk, Poland

Tel. +48 598405 460, e-mail: tkachenko@apsl.edu.pl

J. Grudniewska

Department of Salmonid Research, Rutki, Inland Fisheries Institute in Olsztyn, Poland
}

tissues. Correlative analysis between oxidative stress biomarkers and antioxidant defense confirms the pivotal role of SOD and CAT against CIP-induced oxidative stress.

Keywords: rainbow trout, Oncorhynchus mykiss, peracetic acid, hydrogen peroxide, oxidative stress, antioxidant defense

\section{Introduction}

Efficient prophylactic approaches against fish disease are essential for the continued development of aquaculture. Recent research on substances such as acidic disinfectants, e.g., CIP, Oxim, Steridial, and other disinfecting agents formulated with peracetic acid (PAA), show they have prophylactic effects against bacterial, viral, and fungal infections when administered in a bath (Grudniewska and Dobosz 2007, Grudniewska et al. 2007, 2008).

PAA is used in many industries for its bactericidal, virucidal, fungicidal, and sporicidal effectiveness. It is a strong disinfectant with a wide spectrum of antimicrobial activity even in the presence of heterogeneous organic matter. PAA has no persistent toxic or mutagenic residuals or by-products, is only slightly dependent on $\mathrm{pH}$, and requires brief contact time (Kitis 2004). PAA demonstrated the highest 
disinfectant rate at the lowest concentration when compared in tests with a broad range of other available disinfectants (Baldry 1983). Straus et al. (2012) report the effectiveness of PAA for fungus control on channel catfish, Ictalurus punctatus (Rafinesque), eggs. PAA has recently been suggested for use as a means to control infestations of Ichthyophthirius multifiliis even at low concentrations (Straus and Meinelt 2009). Picon-Camacho et al. (2012) also tested the efficacy of a $\mathrm{H}_{2} \mathrm{O}_{2}$, peracetic, acetic and peroctanoic acid-based formulation in the treatment of free-living stages of Ichthyophthirius multifiliis (tomonts, cysts, and theronts), which is a protozoan parasite of freshwater fish. They showed that the in vitro efficacy of the PAA-based product has great potential to control I. multifiliis infections in commercial aquacultural systems (Picon-Camacho et al. 2012). The results of Elia et al. (2006) showed that antioxidant parameters could be used as biomarkers of oxidative stress during exposure to disinfectants. Antonelli et al. (2006) evaluated the long-term disinfectant efficacy of PAA against fecal coliforms, Escherichia coli, and total heterotrophic bacteria. Treatments with PAA can also be used in freshwater crayfish aquaculture to prevent Aphanomyces astaci infections through effective disinfection. Jussila et al. (2011) also tested the efficacy of PAA on the disinfection or removal of crayfish plague, $A$. astaci, spores in the aquatic environment. They noted that a minimum lag time of $4 \mathrm{~h}$ was sufficient for the breakdown of PAA under practical conditions since there was a $100 \%$ crayfish survival in test groups over two weeks when exposed to PAA-treated water after a treatment lag time of more than $2 \mathrm{~h}$ (Jussila et al. 2011). Hebert et al. (2008) evaluated the impacts of various wastewater disinfection processes on the immune system of juvenile rainbow trout, Oncorhynchus mykiss (Walbaum). T lymphocyte proliferation was stimulated in the PAA treatment group (Hebert et al. 2008).

In general, the disinfection efficiency of PAA for microorganisms is ranked as follows: bacteria $>$ viruses $>$ bacterial spores $>$ protozoan cysts (Liberti and Notarnicola 1999, Rudd and Hopkinson 1989, Kitis 2004). Baldry (1983) compared the antimicrobial properties of aqueous solutions of PAA and hydrogen peroxide $\left(\mathrm{H}_{2} \mathrm{O}_{2}\right)$ against vegetative bacteria, bacterial spores, and yeasts. $\mathrm{H}_{2} \mathrm{O}_{2}$ is more effective as a sporicide than as a bactericide (Baldry 1983). The combination of $\mathrm{PAA}$ and $\mathrm{H}_{2} \mathrm{O}_{2}$ was found to be synergistic (Alasri et al. 1992, 1993).

$\mathrm{H}_{2} \mathrm{O}_{2}$ is commonly used in the aquaculture industry against a range of skin and gill infections. Preliminary success using $\mathrm{H}_{2} \mathrm{O}_{2}$ to treat Atlantic salmon, Salmo salar L., affected with experimentally-induced amoebic gill disease was demonstrated by Adams et al. (2012). $\mathrm{H}_{2} \mathrm{O}_{2}$ is also effective for treating certain external bacterial infections and flagellate infestations in some species of ornamental fish (serpae tetra, Hyphessobrycon eques; tiger barb, Puntius tetrazona; blue gourami, Trichogaster trichopterus; suckermouth catfish, Hypostomus plecostomus; green swordtail, Xiphophorus hellerii; Russo et al. 2007). The effects of treatment with $\mathrm{H}_{2} \mathrm{O}_{2}$ against progressive infection with flatworm parasite, Zeuxapta seriolae, were determined by Mansell et al. (2005). McAndrew et al. (1998) also demonstrated the effects of $\mathrm{H}_{2} \mathrm{O}_{2}$ treatment on different life-cycle stages of the salmon louse, Lepeophtheirus salmonis. The mobile adult and pre-adult stages of $L$. salmonis readily reattached to Atlantic salmon after $\mathrm{H}_{2} \mathrm{O}_{2}$ treatment. Adult female lice reattached in significantly lower numbers than they did in untreated controls (McAndrew et al. 1998).

A number of studies have illustrated that $\mathrm{H}_{2} \mathrm{O}_{2}$ at concentrations in the high physiological range induce adaptive changes increasing the resistance of biological systems not only to oxidative stress but also to many other stimuli (Stone and Yang 2006, Santos et al. 2011). The capability of $\mathrm{H}_{2} \mathrm{O}_{2}$ to induce a large number of protein syntheses and to provide cross-resistance implies that living systems might "intentionally" produce $\mathrm{H}_{2} \mathrm{O}_{2}$ as a component of adaptation in response to different fluctuations and perturbations shifting the system away from homeostasis (Yin et al. 2012).

Recent research on substances such as acidic disinfectants, e.g. disinfecting agents formulated with peracetic acid and hydrogen peroxide, show 
prophylactic effects against bacterial, viral, and fungal infections when administered by bathing. Such disinfectants, although important and effective as disinfecting agents, could also have damaging effects caused by the generation of reactive oxygen species (ROS) and the formation of oxidation products in fish tissues. The following suite of fish biomarkers can be used to assess exposure to or the effects of xenobiotics on aquatic ecosystems: oxidative stress parameters, biotransformation products, stress proteins, metallothioneins, biotransformation enzymes (phases I and II), hematological, immunological, reproductive, endocrine, genotoxic, neuromuscular, physiological, histological, and morphological parameters (Van der Oost et al. 2003). Oxidative stress biomarkers and antioxidant defenses are good diagnostic and prognostic tools to assess the effects of a large number of individual and interactive processes in aquatic organisms (Wilhelm Filho 1996, 2007, Ross et al. 2001).

Thus, the aim of the present work was to study the effect of Disinfectant-CIP formulated with $15 \%$ PAA and $20 \% \mathrm{H}_{2} \mathrm{O}_{2}$ (manufactured by Biochem-Art, Gdansk, Poland) administered as bath treatments on oxidative stress biomarkers and antioxidant defenses in the muscle, gill, hepatic, and cardiac tissues of rainbow trout (O. mykiss).

\section{Materials and methods}

\section{Experimental Fish}

Juvenile rainbow trout aged $0+$ (first year of life) came from spawning performed at the Department of Salmonid Research, Inland Fisheries Institute (Rutki, Żukowo, Poland). The fish were fed daily with feed delivered by band feeders. The daily feed ration was calculated using the applicable feed table, depending on water temperature. Feed was withheld one day prior to experiment. Forty-four clinically healthy rainbow trout (O. mykiss) with a mean body mass of $45.8 \pm 1.2 \mathrm{~g}$ were used in the experiments, which were performed at a water temperature of $16^{\circ} \mathrm{C}( \pm 2)$ and a $\mathrm{pH}$ of 7.5-7.6. The dissolved oxygen level was about 12 ppm with additional oxygen supply. Water temperature and oxygen content were measured daily in the morning with a thermometer and oxygen meter. All enzymatic assays were carried out at the Department of Animal Physiology, Institute of Biology and Environmental Protection, Pomeranian University (Slupsk, Poland).

\section{Experimental Procedure}

The fish were divided into two groups and held in square 2501 tanks (70 fish per tank). The disinfectant agent used was Disinfectant-CIP, a solution for$\begin{array}{lllll}\text { mulated with } 15 \% & \mathrm{PAA} & \text { and } 20 \% & \mathrm{H}_{2} \mathrm{O}_{2}\end{array}$ (Biochem-Art, Gdansk, Poland). It is marketed under license No. 0508/04 from the Minister of Health in Poland (27.01.2004) as a biocidal product under the name DEZYNFEKTANT-CIP (Grudniewska et al. 2008). The fish were exposed to the disinfectant by bathing them in a Disinfectant-CIP solution at a final concentration $16 \mathrm{ml} \mathrm{m}^{-3}$ (Group II). The fish were bathed for $20 \mathrm{~min}$ three times daily every three days in the mornings before feeding. Control fish (Group I) were handled in the same manner as Group II, but without the Disinfectant-CIP treatment. Two days after the last bath, 22 individuals from each group were sampled. The fish were not anesthetized before tissue sampling.

\section{Tissue isolation}

Tissues were removed from the trout after decapitation. One trout was used for each homogenate preparation. Briefly, muscle, gill, hepatic, and cardiac tissues were excised, weighed, and washed in ice-cold buffer. The minced tissues were rinsed clear of blood with cold isolation buffer and homogenized on ice in a glass Potter-Elvehjem homogenizing vessel with a motor-driven pestle. The isolation buffer contained $100 \mathrm{mM}$ Tris-HCl; $\mathrm{pH}$ of 7.20 was adjusted with $\mathrm{HCl}$. 


\section{Analytical methods}

Thiobarbituric acid (TBA), oxidized and reduced glutathione (GSSG and GSH), NADPH, 5,5-dithiobis-2-nitrobenzoic acid (DTNB), ethylenediaminetetraacetic acid (EDTA), thrichloroacetic acid (TCA), quercetin, hydrogen peroxide, ammonium molybdate, sodium aside, t-butylhydroperoxide, Tween 80, urea acid, and 2,4-dinitrophenyl hydrazine (DNFH) were obtained from Fluka (Buchs, Switzerland). All other chemicals were of analytical grade. All enzymatic assays were carried out at $25^{\circ} \mathrm{C}( \pm 0.5)$ using a Specol 11 spectrophotometer (Carl Zeiss Jena, Germany). The enzymatic reactions were started by adding the homogenate suspension. The specific assay conditions are presented subsequently. Each sample was analyzed in triplicate. The protein concentration in each sample was determined according to Bradford (1976) using bovine serum albumin as a standard.

\section{Thiobarbituric acid reactive substrates (TBARS) assay}

The level of lipid peroxidation was determined by quantifying the concentration of 2-thiobarbituric acid reactive substrates (TBARS) with the Kamyshnikov (2004) method for determining the malondialdehyde (MDA) concentration. In the TBARS assay, $2.1 \mathrm{ml}$ tissue homogenate was heated together with $20 \%$ TCA and $0.8 \%$ TBA reagent in boiling water for $10 \mathrm{~min}$. Then the tubes were cooled, and after centrifugation (3,000 $\mathrm{g}$ for $10 \mathrm{~min})$ the absorbance was measured at $540 \mathrm{~nm}$. TBARS values were expressed in nanomoles of MDA equivalents per milligram of protein.

\section{Assay of carbonyl derivative content of protein oxidative modification (OMP)}

As an indication of oxidative damage to proteins, carbonyl groups were measured according to the method of Levine et al. (1990) as modified by Dubinina et al. (1995). Samples were incubated at room temperature for $1 \mathrm{~h}$ with $10 \mathrm{mM}$ DNTP in $2 \mathrm{M}$ $\mathrm{HCl}$. Blanks were run without DNTP. Afterward, proteins were precipitated with TCA and centrifuged for $20 \mathrm{~min}$ at 3,000 g. The protein pellet was washed three times with ethanol:ethylacetate (1:1) and incubated at $37^{\circ} \mathrm{C}$ until complete resuspension. The carbonyl content was measured spectrophotometrically at $370 \mathrm{~nm}$ (aldehyde derivates, $\mathrm{OMP}_{370}$ ) and at 430 $\mathrm{nm}$ (ketonic derivates, $\mathrm{OMP}_{430}$ ) (molar extinction coefficient 22,000 $\mathrm{M}^{-1} \mathrm{~cm}^{-1}$ ) and expressed as nmol per mg protein.

\section{Superoxide dismutase activity assay}

Superoxide dismutase (SOD, E.C. 1.15.1.1) activity in supernatant was determined according to Kostiuk et al. (1990). SOD activity was assessed by its ability to dismutate superoxide produced during quercetin auto-oxidation in an alkaline medium ( $\mathrm{pH}$ 10.0). Briefly, $1.0 \mathrm{ml}$ of $\mathrm{C}$ reagent was mixed with $0.1 \mathrm{ml}$ of homogenate (1:1000). C reagent was made ex tempore (mixture of equal volumes of $0.1 \mathrm{M}$ K/Na-phosphate buffer, pH 7.8, and 0.08M EDTA); the $\mathrm{pH}$ of the $\mathrm{C}$ reagent was adjusted to 10.0 by adding tetramethylenediamine. Distilled water $(0.1 \mathrm{ml})$ was added to the blank instead of homogenate. The total volume was then made up to $2.4 \mathrm{ml}$ with distilled water. The reaction was initiated by adding 0.1 $\mathrm{ml}$ of quercetin $(1.4 \mu \mathrm{M})$. Absorbance at $406 \mathrm{~nm}$ was measured immediately and again after $20 \mathrm{~min}$. Activity was expressed in units of SOD per mg of tissue protein.

\section{Catalase activity assay}

Catalase (CAT; EC 1.11.1.6) activity was determined by measuring the decrease of $\mathrm{H}_{2} \mathrm{O}_{2}$ concentration at $410 \mathrm{~nm}$ according to Koroliuk et al. (1988). The rate of decrease in $\mathrm{H}_{2} \mathrm{O}_{2}$ content is directly proportional to the CAT activity in the sample. Assays were performed in a reaction mixture containing $2 \mathrm{ml}$ of $0.03 \% \mathrm{H}_{2} \mathrm{O}_{2}$ solution and $0.1 \mathrm{ml}$ of tissue homogenate. The duration of this reaction was $10 \mathrm{~min}$ at room temperature. The reaction was terminated by 
rapidly adding $1.0 \mathrm{ml}$ of $4 \%$ ammonium molybdate dissolved in $12.5 \mathrm{mM} \mathrm{H}_{2} \mathrm{SO}_{4}$ and $1 \mathrm{ml}$ of $125 \mathrm{~mm}$ $\mathrm{H}_{2} \mathrm{SO}_{4}$. Instead of the homogenate, the blank assay included $0.1 \mathrm{ml}$ of distilled water. All samples were centrifuged at 3,000 $\mathrm{g}$ for $10 \mathrm{~min}$. One unit of CAT activity was defined as the decrease of $1 \mu \mathrm{mol}$ of $\mathrm{H}_{2} \mathrm{O}_{2}$ per minute per milligram protein.

\section{Glutathione reductase activity assay}

Glutathione reductase (GR, EC 1.6.4.2) activity was assayed as described by Glatzle et al. (1974) with some modifications. The enzymatic activity was assayed spectrophotometrically by measuring NADPH consumption. In the presence of GSSG and NADPH, GR reduces GSSG and oxidizes NADPH, resulting in a decrease of absorbance at $340 \mathrm{~nm}$. Quantification was based on the molar extinction coefficient of 6.22 $\mathrm{mM}^{-1} \mathrm{~cm}^{-1}$ of NADPH. One unit of GR was defined as the amount of enzyme that reduced $1 \mu \mathrm{mol}$ of NADPH with GSSG per minute per mg protein.

\section{Glutathione peroxidase activity assay}

Glutathione peroxidase (GPx, EC 1.11.1.9) activities were determined by detecting the nonenzymatic utilization of GSH as the reacting substrate at an absorbance of $412 \mathrm{~nm}$ after incubation with DTNB according to the method of Moin (1986). Briefly, the reaction mixture contained $0.8 \mathrm{ml}$ of $0.1 \mathrm{M}$ Tris- $\mathrm{HCl}$ buffer ( $\mathrm{pH} 8.9$ ) with $12 \mathrm{mM}$ sodium azide, $6 \mathrm{mM}$ EDTA, $0.2 \mathrm{ml}$ of homogenate, $0.1 \mathrm{ml}$ of $4.8 \mathrm{mM}$ glutathione, and $0.1 \mathrm{ml}$ of $20 \mathrm{mM}$ t-butylhydroperoxide. The contents were incubated at $37^{\circ} \mathrm{C}$ for 10 min. The reaction was arrested by $0.2 \mathrm{ml}$ of $20 \%$ TCA, and centrifuged. The supernatant was assayed for glutathione content with Ellman's reagent (39.6 $\mathrm{mg}$ of DTNB in $10 \mathrm{ml}$ of $1 \%$ sodium citrate). A unit of enzyme activity is defined as the amount of enzyme catalyzing the formation of $1 \mu \mathrm{mol}$ of GSH per min, and the activity of GPx was calculated based on tissue protein concentration.

\section{Total antioxidant capacity (TAC) assay}

The TAC level was estimated spectrophotometrically at $532 \mathrm{~nm}$ following the method with Tween 80 oxidation (Galaktionova et al. 1998). Briefly, $0.2 \mathrm{ml}$ of tissue homogenate was added to $2 \mathrm{ml}$ of $1 \%$ Tween 80. Instead of the sample, the blank assay included $0.1 \mathrm{ml}$ of distilled water. The mixture was incubated for 48 hours at $37^{\circ} \mathrm{C}$. After cooling, $1 \mathrm{ml}$ of $40 \%$ TCA was added. The mixture was centrifuged at 3,000 $\mathrm{g}$ for $10 \mathrm{~min}$. After centrifugation, $2 \mathrm{ml}$ of supernatant and $2 \mathrm{ml}$ of $0.25 \%$ TBA reagent were mixed in. The mixture was heated in a boiling water bath at $100^{\circ} \mathrm{C}$ for 15 minutes. The absorbance of the solution obtained was measured at $532 \mathrm{~nm}$ and was compared with the blank. The TAC level was expressed in \%.

\section{Statistical analysis}

The results obtained were analyzed statistically using the Statistica 10.0 software package (StatSoft, Poland). The results are expressed as means \pm S.E.M. The Kolmogorov-Smirnov test was applied to evaluate normality, while the Levene test was used to test the homogeneity of variance. As most of the distributions deviated from the normal distribution, non-parametric tests were used for further analyses. To assess the differences between the studied group and untreated control, the non-parametric Mann-Whitney $U$-test was used, and P-values of less than 0.05 were considered significant (Zar 1999).

\section{Results}

TBARS as biomarkers of lipid peroxidation as well as protein carbonyl contents as biomarkers of protein oxidation in muscle, gill, hepatic, and cardiac tissues of rainbow trout (O. mykiss) exposed to Disinfectant-CIP are presented in Figures 1 and 2. Muscle TBARS content was lower by $24 \%(\mathrm{P}=0.047)$, and no significant difference was found in the TBARS content of gill, hepatic, or cardiac tissues after Disinfectant-CIP treatment (Fig. 1). 


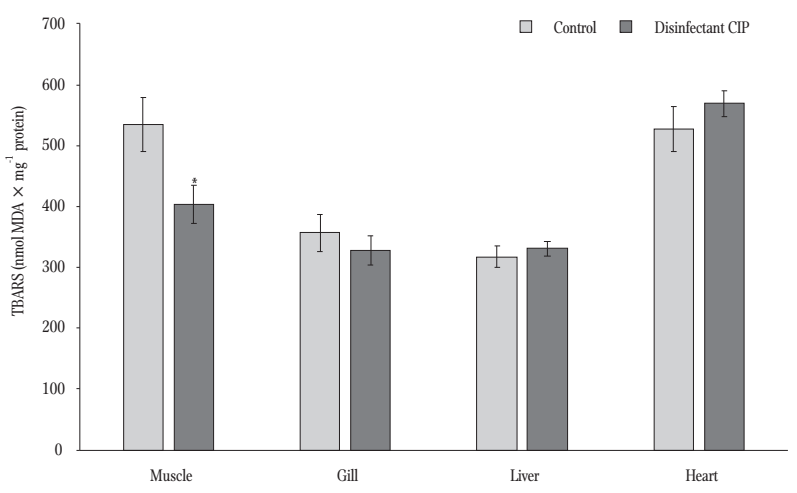

Figure 1. Level of lipid peroxidation (nmol MDA per mg protein) in muscle, gill, liver, and heart tissues of rainbow trout (O. mykiss) treated with Disinfectant-CIP formulated with peracetic acid and hydrogen peroxide. *indicates significant difference from the untreated group $(\mathrm{P}<0.05)($ mean \pm S.E.M. $)$
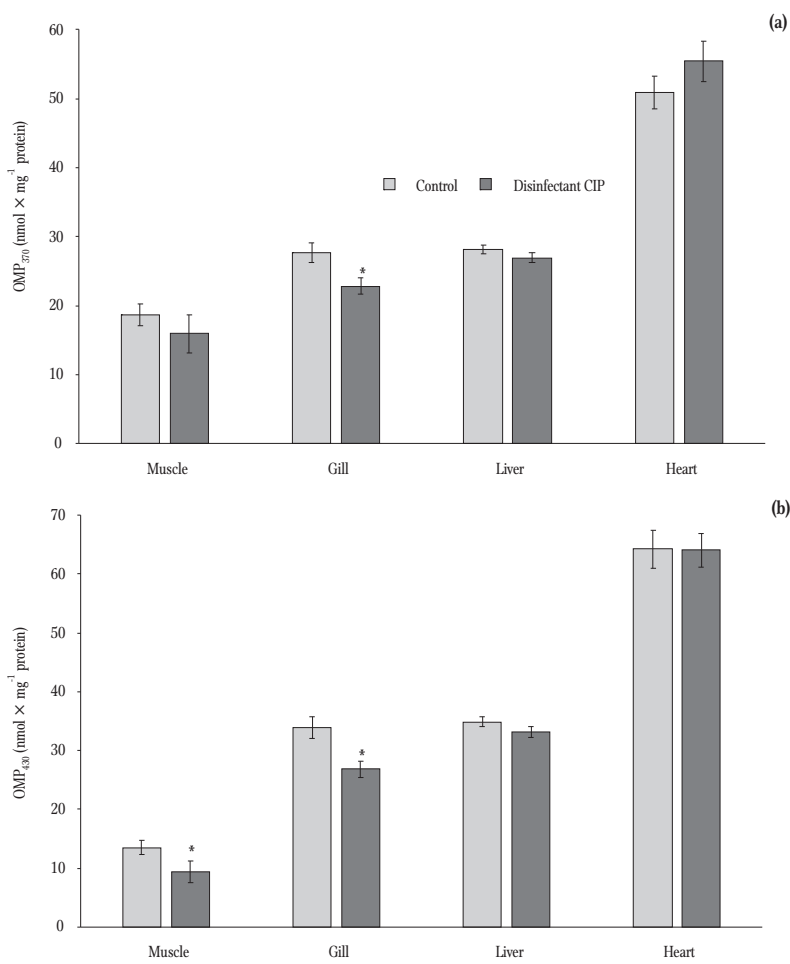

Figure 2. Aldehyde (a) and ketonic derivates (b) of carbonyl content in the muscle, gill, liver, and heart tissues of rainbow trout $(O$. mykiss) treated with Disinfectant-CIP formulated with peracetic acid and hydrogen peroxide. *indicates significant difference from the untreated group $(\mathrm{P}<0.05)$ (mean \pm S.E.M.)

As biomarkers of oxidative stress, carbonyl content showed non-significant changes between the untreated and CIP-exposed groups except in muscle and gill tissues (Fig. 2). The ketonic derivates of

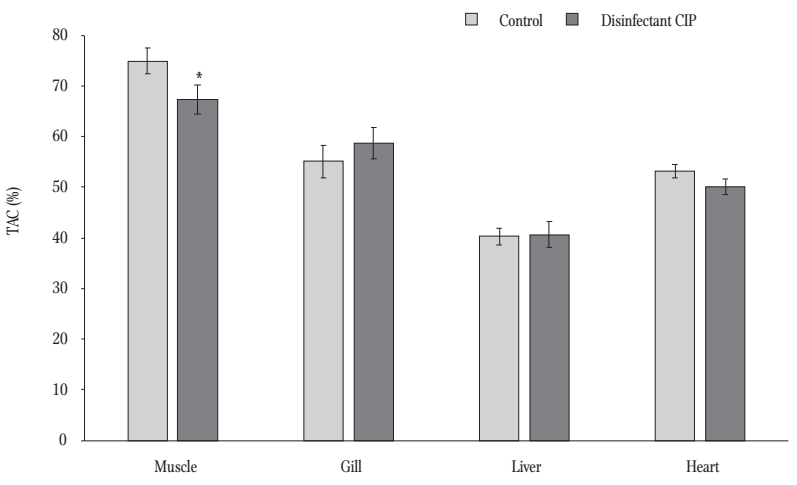

Figure 3. Total antioxidant capacity in the muscle, gill, liver, and heart tissues of rainbow trout $(O$. mykiss) treated with Disinfectant-CIP formulated with peracetic acid and hydrogen peroxide. *indicates significant difference from the untreated group $(\mathrm{P}<$ 0.05) (mean \pm S.E.M.)

protein carbonyl content in muscle and gill tissues of CIP-exposed trout were lower by $31 \%(\mathrm{P}=0.003)$ and by $21 \%(\mathrm{P}=0.003)$, respectively, compared to the control group (Fig. 2). Aldehyde derivates of oxidatively modified proteins in gill tissue of CIP-exposed trout were also lower by $17.5 \%(\mathrm{P}=$ 0.007) (Fig. 2).

Antioxidant enzyme activities in muscle, gill, hepatic, and cardiac tissues of rainbow trout exposed to Disinfectant-CIP are shown in Tables 1 and 2. After Disinfectant-CIP exposure, muscle, hepatic, and cardiac SOD activities were lower by $25 \%(\mathrm{P}=$ $0.000), 38 \%(\mathrm{P}=0.005)$, and $43 \%(\mathrm{P}=0.000)$, respectively, compared to the control group. CAT activity in the muscle and cardiac tissues was lower by $31 \%(\mathrm{P}=0.007)$ and 26\% $(\mathrm{P}=0.008)$, respectively. Statistically significant differences in muscle and hepatic GR activity was observed between CIP-treated and control trout. Cardiac and hepatic GPx activity of the CIP-exposed group was higher by $28 \%(\mathrm{P}=0.047)$ and $26 \%(\mathrm{P}=0.008)$, respectively, compared to the control group. Gill GPx activity was lower by $25 \%(\mathrm{P}=0.004)$ in CIP-treated group.

Regarding total antioxidative capacity (Fig. 3), Disinfectant-CIP significantly decreased muscle TAC by $10 \%(\mathrm{P}=0.030)$. No significant differences of TAC in gill, hepatic, or cardiac tissues for CIP-treated trout were observed. Data from correlation analysis 
Table 1

Antioxidant enzyme activities in muscle and gill tissues of rainbow trout (O. mykiss) exposed to Disinfectant-CIP formulated with peracetic acid and hydrogen peroxide. SOD - superoxide dismutase, CAT - catalase, GR - glutathione reductase, GPx glutathione peroxidase

\begin{tabular}{|c|c|c|c|c|}
\hline \multirow[b]{2}{*}{ Antioxidant enzymes } & \multicolumn{2}{|l|}{ Muscle } & \multicolumn{2}{|l|}{ Gill } \\
\hline & Control & Disinfectant-CIP & Control & Disinfectant-CIP \\
\hline SOD (U mg-1 protein) & $801.75 \pm 19.10$ & $604.21 \pm 29.24^{*}$ & $309.17 \pm 43.97$ & $327.77 \pm 32.69$ \\
\hline $\operatorname{CAT}\left(\mu \mathrm{mol} \mathrm{H}_{2} \mathrm{O}_{2} \min ^{-1} \mathrm{mg}^{-1}\right.$ protein $)$ & $20.48 \pm 1.41$ & $14.09 \pm 1.68 *$ & $8.71 \pm 1.18$ & $9.87 \pm 0.74$ \\
\hline GR ( $\mu$ mol NADPH $2 \min ^{-1} \mathrm{mg}^{-1}$ protein $)$ & $8.18 \pm 0.95$ & $3.92 \pm 0.50 *$ & $5.26 \pm 0.53$ & $5.56 \pm 0.66$ \\
\hline GPx ( $\mu \mathrm{mol} \mathrm{GSH} \min ^{-1} \mathrm{mg}^{-1}$ protein $)$ & $207.87 \pm 15.74$ & $253.66 \pm 19.90$ & $203.98 \pm 10.41$ & $152.67 \pm 13.92 *$ \\
\hline
\end{tabular}

*indicates significant difference from the control group $(\mathrm{P}<0.05)$ (mean \pm S.E.M.)

Table 2

Antioxidant enzyme activities in liver and heart tissues of rainbow trout (O. mykiss) exposed to Disinfectant-CIP formulated with peracetic acid and hydrogen peroxide. SOD - superoxide dismutase, CAT - catalase, GR - glutathione reductase, GPx glutathione peroxidase

\begin{tabular}{|c|c|c|c|c|}
\hline \multirow[b]{2}{*}{ Antioxidant enzymes } & \multicolumn{2}{|l|}{ Liver } & \multicolumn{2}{|l|}{ Heart } \\
\hline & Control & Disinfectant-CIP & Control & Disinfectant-CIP \\
\hline SOD (U mg-1 protein) & $395.40 \pm 41.52$ & $245.45 \pm 20.67 *$ & $753.58 \pm 27.99$ & $425.87 \pm 26.74^{*}$ \\
\hline CAT $\left(\mu \mathrm{mol} \mathrm{H}{ }_{2} \mathrm{O}_{2} \mathrm{~min}^{-1} \mathrm{mg}^{-1}\right.$ protein $)$ & $20.31 \pm 0.47$ & $18.98 \pm 0.45$ & $39.84 \pm 2.38$ & $29.58 \pm 2.48^{*}$ \\
\hline $\mathrm{GR}\left(\mu \mathrm{mol} \mathrm{NADPH} \mathrm{min}^{-1} \mathrm{mg}^{-1}\right.$ protein $)$ & $6.44 \pm 0.83$ & $2.87 \pm 0.35^{*}$ & $2.66 \pm 0.26$ & $2.75 \pm 0.28$ \\
\hline 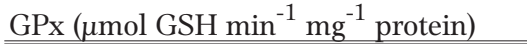 & $14.40 \pm 1.39$ & $18.41 \pm 1.13^{*}$ & $223.38 \pm 19.59$ & $281.47 \pm 13.97^{*}$ \\
\hline
\end{tabular}

*indicates significant difference from the control group $(\mathrm{P}<0.05)$ (mean \pm S.E.M.)

among lipid peroxidation, oxidative modified protein levels, and antioxidant enzyme activity in different tissues of rainbow trout from the control group and the group exposed to Disinfectant-CIP are shown in Figures 4-7. In the untreated control group, muscle TAC was determined by GR ( $\mathrm{r}=0.697, \mathrm{P}=0.000)$ and GPx activity $(\mathrm{r}=0.493, \mathrm{P}=0.020)$, while the decrease of ketonic derivates of protein carbonyl content depended on CAT and SOD activity in the CIP-treated group (Fig. 4). In gill tissue, the TBARS level was correlated with SOD $(\mathrm{r}=0.491, \mathrm{P}=0.020)$ and GPx activity ( $\mathrm{r}=0.471, \mathrm{P}=0.027)$ in the untreated group (Fig. 5a). The decreases of aldehyde and the ketonic derivates of protein carbonyl content resulted from lower GPx activity in the gill tissues of the CIP-exposed group (Fig. 5b). Hepatic SOD activity correlated with oxidative stress biomarkers in the control group (Fig. 6a). In the CIP-exposed group, the hepatic TBARS level was correlated with SOD activity $(\mathrm{r}=-0.524, \mathrm{P}=0.018)$ and the aldehyde level of oxidatively modified proteins $(\mathrm{r}=0.796, \mathrm{P}=0.000)$
(Fig. 6b). The relationship between oxidative stress parameters in the cardiac tissue of the control group and the group exposed to Disinfectant-CIP was positive (Fig. 7a). The cardiac TBARS level was correlated with GR activity ( $\mathrm{r}=0.547, \mathrm{P}=0.013)$ in the CIP-exposed group (Fig. 7b).

\section{Discussion}

The aim of this study was to evaluate the effect of Disinfectant-CIP, formultaed with PAA and $\mathrm{H}_{2} \mathrm{O}_{2}$, on oxidative stress biomarkers and antioxidant defenses in the muscle, gill, hepatic, and cardiac tissues of rainbow trout. The findings of this study showed that lipid peroxidation in muscle tissues decreased in the CIP-exposed group when compared with the control group (Fig. 1). TBARS content as biomarker of lipid peroxidation in the gill tissue showed a downward trend after the disinfectant treatment. Similarly, the oxidative modification of protein also showed 

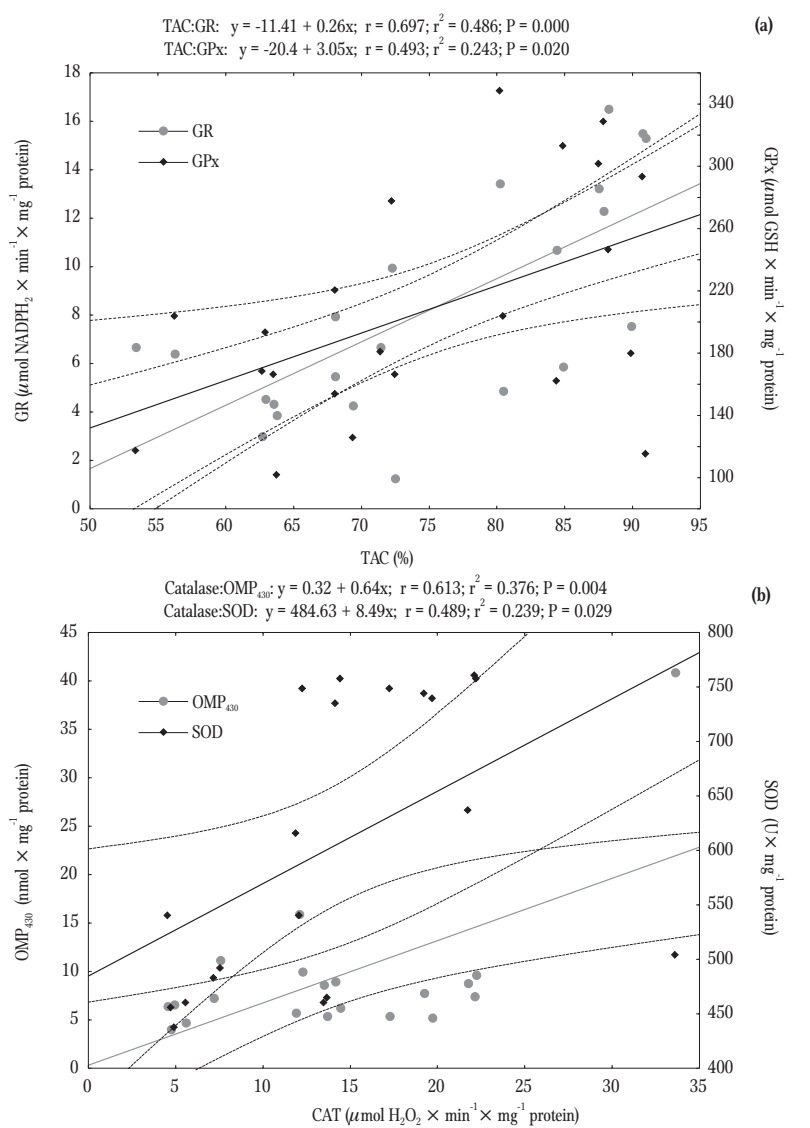

Figure 4. Correlation between TAC, GR, and GPx activity (a), and CAT and SOD activity (b), and ketonic derivates of oxidatively modified protein levels in the muscle tissues of the control group and rainbow trout (O. mykiss) exposed to Disinfectant-CIP.

a downward trend after disinfection treatment in muscle and gill tissues. No significant changes were noted in this study in the oxidative stress biomarkers (TBARS content as a biomarker of lipid peroxidation and carbonyl content as the oxidative damage of proteins) of hepatic and cardiac tissues in the CIP-treated group compared with the control group (Figs. 1 and 2).

In our study, the CIP-treated group showed decreased SOD activity in muscle, hepatic, and cardiac tissues, while higher activity was noted in the control group. CAT activity in muscle and cardiac tissues also showed similar trends. We assume that the excessive release of superoxide radicals after Disinfectant-CIP exposure can cause a decrease of SOD and CAT activity. Moreover, it is noted that SOD and CAT play a pivotal role in decreasing the oxidative stress
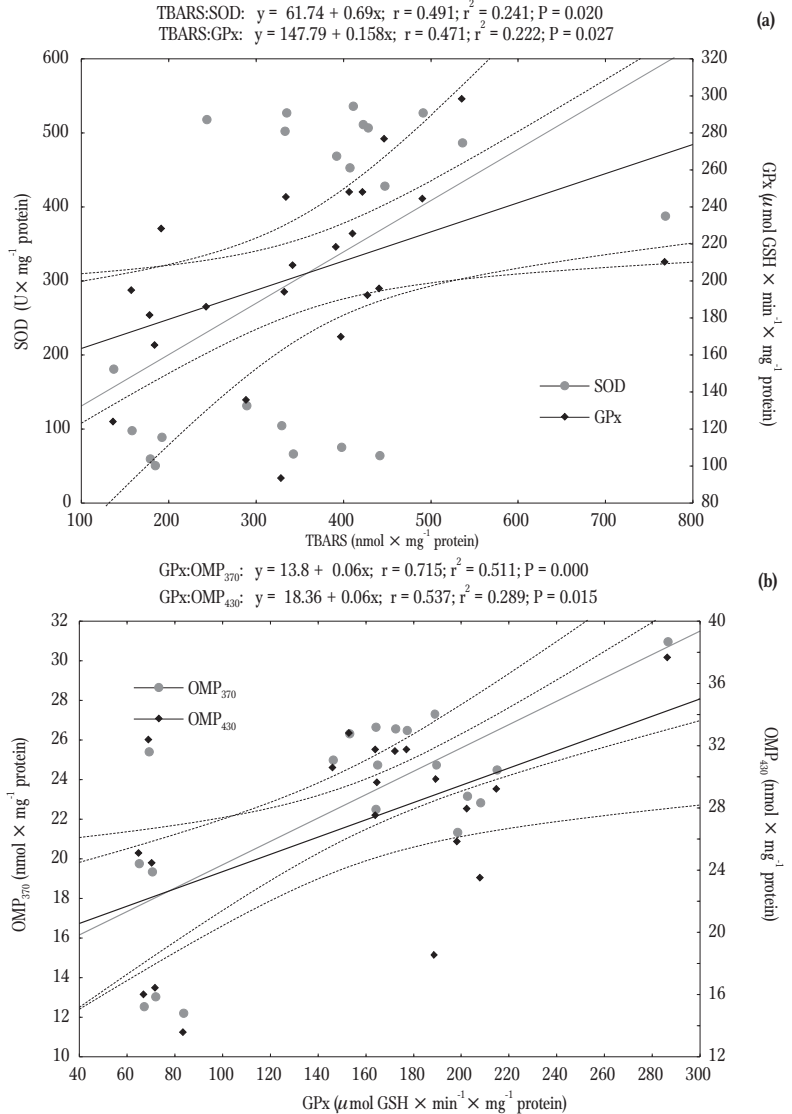

Figure 5. Correlation between TBARS level, SOD, and GPx activity (a), and GPx activity (b), aldehyde and ketonic derivates of oxidatively modified protein levels in the gill tissue of the control group and rainbow trout (O. mykiss) exposed to Disinfectant-CIP.

biomarker level in the muscle, gill, and hepatic tissues of the CIP-treated group (Figs. 4-6, Table 1). TAC decreased only in the muscle tissue of trout treated with Disinfectant-CIP (Fig. 3). In contrast, the GPx activity trend in both cardiac and hepatic tissues was increasing, while it was decreasing in gill tissue after disinfectant treatment. The correlation between the carbonyl level of protein damage and GPx activity in gill tissue confirms the assumption about the role of GPx in oxidative stress reduction. Similarly, correlative analysis among TBARS, aldehyde derivates of oxidatively modified protein levels, and GR activity showed the role of glutathione-dependent antioxidant defense in cardiac tissue of the CIP-treated group (Fig. 7).

Differences in tissue response to the influence of the Disinfectant-CIP could be explained by the 


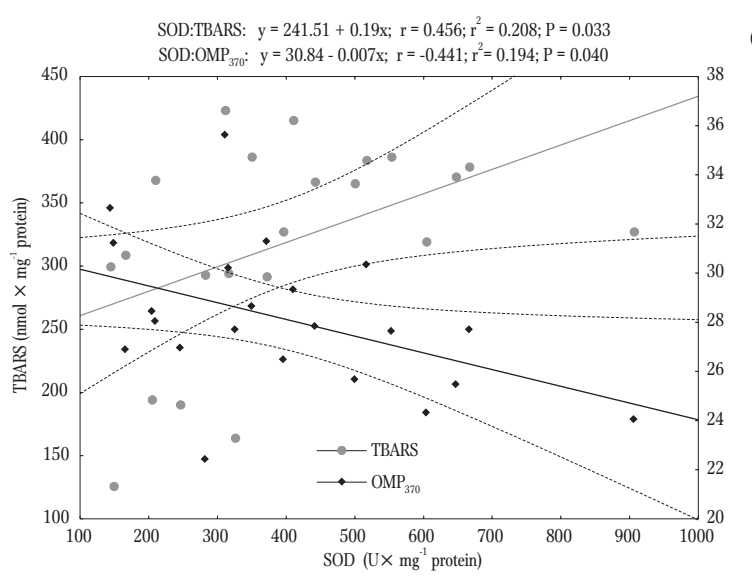

(a)

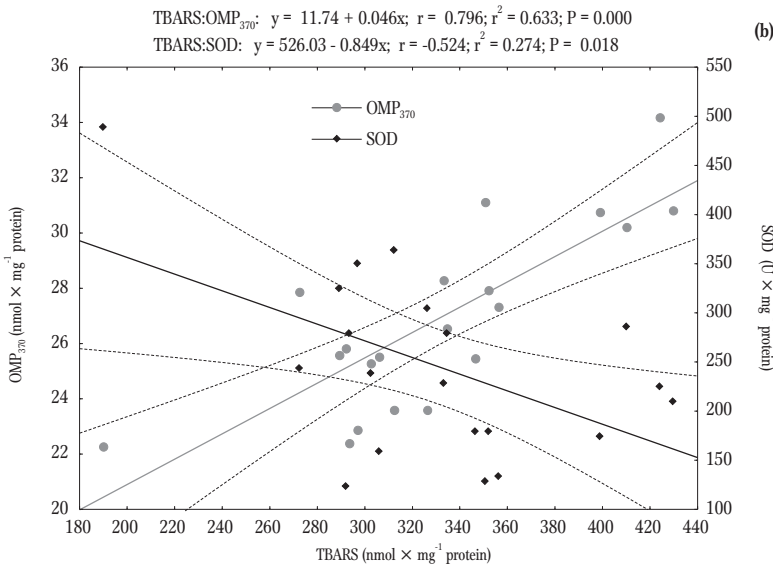

Figure 6. Correlation between SOD activity (a), TBARS (b) and aldehyde derivates of oxidatively modified protein level in the hepatic tissue of the control group (A) and rainbow trout $(O$. mykiss) exposed to Disinfectant-CIP.

different mechanisms of PAA and $\mathrm{H}_{2} \mathrm{O}_{2}$ action, as well as different distributions of antioxidants among cell and tissues. PAA combines the active oxygen characteristics of peroxide within an acetic acid molecule and belongs to the class of organic peroxides, which are synthetic chemicals. Organic peroxides can contain peroxide radicals (oxygen-oxygen bond) that are a source of oxygen (Kitis 2004). PAA was found to be an efficient disinfecting agent, and was not only bacteriostatic, but it was also a bactericide (Antonelli et al. 2006). PAA action oxidizes the outer cell membrane of cells. The mechanism of oxidation is the transfer of electrons, therefore the stronger the oxidizer, the faster the electrons are transferred to cells and the faster the cells are inactivated or killed. Therefore, PAA has a higher oxidation potential
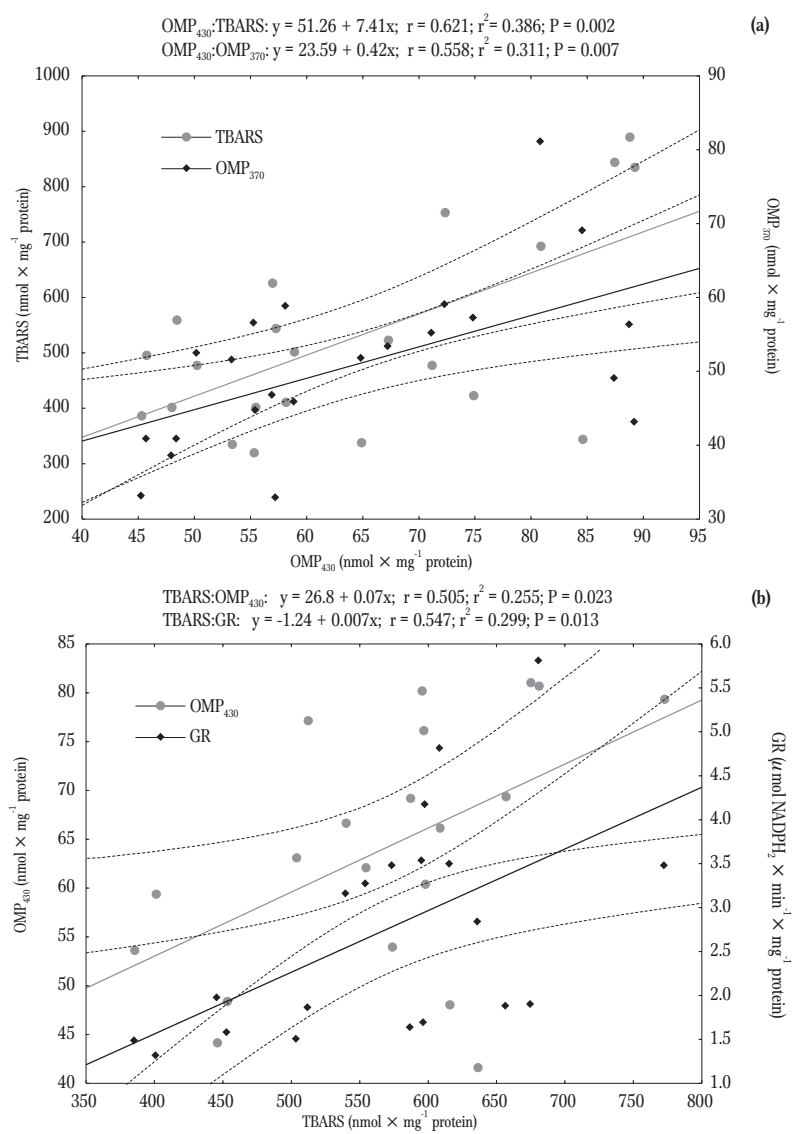

Figure 7. Correlation between TBARS, aldehyde and ketonic derivates of oxidatively modified protein level (a), and TBARS, ketonic derivates of oxidatively modified protein level, and GR activity (b) in the cardiac tissue of the control group and rainbow trout (O. mykiss) exposed to Disinfectant-CIP.

(Marjani et al. 2010). PAA can damage all types of macromolecules associated with microorganisms carbohydrates, nucleic acids (mutations), lipids (lipid peroxidation) and amino acids because the denaturation of proteins and enzymes and increased cell wall permeability by the breaking of sulfhydryl and disulfide bonds results in cell lysis and true microbial death (Baldry 1983, Marjani et al. 2010). Thus, the primary mode of PAA action is oxidative stress through the oxidation of cell macromolecules.

Oxidative stress is a condition characterized by the elevation in the cellular steady-state concentration of reactive oxygen species (ROS) from an imbalance between the production of ROS and the destruction by antioxidant enzymes (Halliwell and Gutteridge 2007). Manipulations that increase ROS 
generation or decrease the antioxidant capacity of cells lead to a state of oxidative stress. A number of antioxidant enzymes are expressed at the same time to protect the cells from the cytotoxic effects of ROS directed against engulfed microorganisms (Ebert-Dümig et al. 1999). On the other hand, in living organisms, besides its well-known cytotoxic effects, ROS play an essential role in regulating diverse biological processes such as immune cell activation (macrophage activation and phagocytosis) and apoptosis (Yin et al. 2012). Macrophage activation and the phagocytosis of foreign particles are regularly accompanied by a so called "respiratory burst", an increase in the production of ROS, exerted by the enzyme complex NADPH oxidase.

Hydrogen peroxide induces production of $\mathrm{O}_{2}{ }^{--}$by activating NADPH oxidase (Coyle et al. 2006). A number of studies have illustrated that, at concentrations in the high physiological range, $\mathrm{H}_{2} \mathrm{O}_{2}$ induces adaptive changes, increasing protein synthesis and provides cross-resistance (Stone and Yang 2006, Santos et al. 2011). Moreover, living systems may "intentionally" produce $\mathrm{H}_{2} \mathrm{O}_{2}$ as a component of adaptation in response to different fluctuations and perturbations shifting the system away from homeostasis (Yin et al. 2012).

Some investigators have studied the effects of PAA and $\mathrm{H}_{2} \mathrm{O}_{2}$ on various organs. The study by Ferraris et al. (2005) showed the effects of disinfection on the formation of toxic compounds in lake water treated with sodium hypochlorite, chlorine dioxide, and PAA and its potential toxic effects on rainbow trout hepatocytes. None of the water concentrates showed any cytotoxic effect or variations in GSH content in rainbow trout hepatocytes, but significant increases in ROS production were detected in fall water concentrates from treatments with sodium hypochlorite and chlorine dioxide. Cytochrome P450 expression was not modified in the hepatocytes exposed to the water concentrates. PAA caused a decrease in GSH and a statistically significant increase in oxygen radicals in hepatocyte cells exposed for 2 $\mathrm{h}$, while prolonged treatment $(24 \mathrm{~h})$ caused a GSH increase, without variations in the ROS content. This phenomenon could be interpreted as the cellular adaptation response to initial oxidative stress (Marabini et al. 2006).

Since the primary mode of PAA and $\mathrm{H}_{2} \mathrm{O}_{2}$ action is the oxidation of cell membranes, we assumed that CIP-induced oxidative stress is limited by antioxidant defenses in the tissues of rainbow trout. In liver and heart tissues of the CIP-treated group, oxidative stress could have been restricted by intracellular GPx, while SOD and CAT activity were inhibited (Table 2).

Different subcellular sites and different cell types can contain varying amounts of antioxidant enzymes (Sies 1997). All cells in eukaryotic organisms contain powerful antioxidant enzymes (Halliwell and Gutteridge 2007). Antioxidants systems prevent the uncontrolled formation of ROS, or inhibit their reactions with biological structures. Hydrophilic scavengers are found in cytosolic, mitochondrial, and nuclear compartments (Chaudière and Ferrari-Iliou 1999). The three major classes of antioxidant enzymes are SOD, CAT, and GPx. In addition, numerous specialized antioxidant enzymes react with and detoxify oxidant compounds. Indirect antioxidant functions carried out by enzymes are: (a) the back-up function, e.g., the replenishment of GSH from glutathione disulphide (GSSG) by the GR; (b) the transport and elimination of reactive compounds, e.g., glutathione S-transferases and the transport systems for glutathione S-conjugates. SOD can catalyze the dismutation of the superoxide radical to $\mathrm{H}_{2} \mathrm{O}_{2}$ and molecular oxygen. Then it can be converted to $\mathrm{H}_{2} \mathrm{O}$ by CAT and GPx (Yin et al. 2012). As an important component of antioxidant defense system in fish, tripeptide glutathione (GSH) directly or indirectly regulates the scavenging of ROS and their reaction products. Additionally, several GSH-associated enzymes such as GR, GPx, and glutathione-S-transferase cumulatively protect fish against ROS, and their reaction products accrue anomalies under oxidative stress (Srikanth et al. 2013). There are synergistic interactions between GSH and other components of the antioxidant defense system such as vitamin C, vitamin E, and SOD (Meister 1994, Gerard-Monnier and Chaudière 1996). Synergistic and co-operative interactions of antioxidants rely on 
the sequential degradation of peroxides and free radicals as well as on the mutual protection of enzymes. The antioxidant network plays an important role in the regulation of protein expression and/or activity at the transcriptional or post-translational levels (Chaudière and Ferrari-Iliou 1999). Elia et al. (2006) assessed the effects of sodium hypochlorite, chlorine dioxide, and PAA treatment for 10 and 20 days on antioxidant response (enzymatic activities of glutathione S-transferases, glyoxalase I, glyoxalase II, GPx, GR, CAT, and total glutathione content) of carp, Cyprinus carpio L. Differences in biochemical parameters were observed in specimens following exposure to these disinfectants, and mainly chlorine compounds induced marked biochemical variations of carp liver compared to those induced by PAA treatment (Elia et al. 2006).

In our study, the CIP-treated group showed decreased SOD and CAT activity in muscle, hepatic, and cardiac tissues (Table 1). GPx activity increased in both the hepatic and cardiac tissues of trout treated with Disinfectant-CIP (Table 2). This could be an adaptive response to the disinfecting procedure which neutralizes the impact of ROS and could be of importance in preventing membrane lipid peroxidation when the latter is initiated by a combination of $\mathrm{Fe}^{3+}$ and $\mathrm{O}_{2}^{-}$generating system. GPx acts on lipid hydroperoxide substrates that are released from membrane phospholipids (Van Kuijk et al. 1987).

The gill and cardiac tissues of CIP-treated rainbow trout displayed positive correlations between oxidative stress biomarkers and glutathione-dependent antioxidant enzymes, while SOD and CAT activity play a pivotal role against CIP-induced oxidative stress in hepatic and muscle tissues. SOD catalyzes the conversion of superoxide radicals into hydrogen peroxide and molecular oxygen, and plays a critical role in the defense of cells against the toxic effects of oxygen radicals (Yim et al. 1990). Catalase is a ubiquitous antioxidant enzyme that is involved in the detoxification of $\mathrm{H}_{2} \mathrm{O}_{2}$ to molecular oxygen and two molecules of water (Halliwell and Gutteridge 2007).
Changes in CAT activity in cardiac and muscle tissues were more pronounced than those in gill and liver tissues. The robust protective effect of CAT activity can be exerted under synergetic effects with SOD activity (Fig. 4b). The inhibition in SOD and CAT activity in the muscle, hepatic, and cardiac tissues was probably observed because of increased ROS generation during CIP-induced oxidative stress; however, hepatic and cardiac GPx activity was increased in an attempt to counteract oxidative stress. The results show that Disinfectant-CIP induced increased GPx activity in liver and heart tissues for attenuating oxidative stress. We suggested that ROS generation under the oxidation of peracetic acid and hydrogen peroxide could be counteracted by the antioxidant defences in tissues of Disinfectant-CIP treatment. In the present study, we found that the level of oxidative stress biomarkers decreased in muscle and gill tissues, while it was not altered in the cardiac and hepatic tissues of rainbow trout after exposure to the Disinfectant-CIP. Thus, Disinfectant-CIP in the final concentration of $16 \mathrm{ml}$ per $\mathrm{m}^{3}$ can be used as a safe disinfecting agent in rainbow trout aquacuture. The data provide important information for future research of disinfectant effects on oxidative stress and antioxidant defenses biomarkers in different tissues of rainbow trout.

Acknowledgments. This study was supported by a grant from the Pomeranian University for Young Scientists.

Author contributions. H.T. and N.K. performed the experiment, analyzed the data, and wrote the paper. J.G. designed and performed the experiment.

\section{References}

Adams M.B., Crosbie P.B.B., Nowak B.F. 2012 - Preliminary success using hydrogen peroxide to treat Atlantic salmon, Salmo salar L., affected with experimentally induced amoebic gill disease (AGD) - J. Fish Dis. 35: 839-848.

Alasri A., Roques C., Michel G., Cabassud C., Aptel P. 1992 Bactericidal properties of peracetic acid and hydrogen peroxide, alone and in combination, and chlorine and 
formaldehyde against bacterial water strains - Can. J. Microbiol. 38: 635-642.

Alasri A., Valverde M., Roques C., Michel G., Cabassud C., Aptel P. 1993 - Sporocidal properties of peracetic acid and hydrogen peroxide, alone and in combination, in comparison with chlorine and formaldehyde for ultrafiltration membrane disinfection - Can. J. Microbiol. 39: 52-60.

Antonelli M., Rossi S., Mezzanotte V., Nurizzo C. 2006 - Secondary effluent disinfection: PAA long term efficiency Environ. Sci. Technol. 40: 4771-4775.

Baldry M.G.C. 1983 - The bactericidal, fungicidal and sporicidal properties of hydrogen peroxide and peracetic acid - J. Appl. Bacteriol. 54: 417-423.

Bradford M.M. 1976 - A rapid and sensitive method for the quantitation of microgram quantities of protein utilizing the principle of protein-dye binding - Anal. Biochem. 72: 248-254.

Chaudière J., Ferrari-Iliou R. 1999 - Intracellular antioxidants: from chemical to biochemical mechanisms - Food Chem. Toxicol. 37: 949-962.

Coyle C.H., Martinez L.J., Coleman M.C., Spitz D.R., Weintraub N.L., Kader K.N., 2006 - Mechanisms of $\mathrm{H}_{2} \mathrm{O}_{2}$-induced oxidative stress in endothelial cells - Free Radic. Biol. Med. 40: 2206-2213.

Dubinina E.E., Burmistrov S.O., Khodov D.A., Porotov I.G. 1995 - Oxidative modification of human serum proteins. A method of determining it - Vopr. Med. Khim. 41: 24-26 (in Russian with English abstract).

Ebert-Dümig R., Seufert J., Schneider D., Köhrle J., Schütze N., Jakob F. 1999 - Expression of selenoproteins in monocytes and macrophages - implicationen for immune system - Med. Klin. (Munich) 94: 29-34 (in German).

Elia A.C., Anastasi V., Dörr A.J. 2006 - Hepatic antioxidant enzymes and total glutathione of Cyprinus carpio exposed to three disinfectants, chlorine dioxide, sodium hypochlorite and peracetic acid, for superficial water potabilization - Chemosphere 64: 1633-1641.

Ferraris M., Chiesara E., Radice S., Giovara A., Frigerio S., Fumagalli R., Marabini L. 2005 - Study of potential toxic effects on rainbow trout hepatocytes of surface water treated with chlorine or alternative disinfectants Chemosphere 60: 65-73.

Galaktionova L.P., Molchanov A.V., El'chaninova S.A., Varshavskii B.I. 1998 - Lipid peroxidation in patients with gastric and duodenal peptic ulcers - Klin. Lab. Diagn. 6: 10-14 (in Russian, with English abstract)

Gérard-Monnier D., Chaudiere J. 1996 - Metabolism and antioxidant function of glutathione - Pathol. Biol. 44: 77-85.

Glatzle D., Vuilleumier J.P., Weber F., Decker K. 1974 Glutathione reductase test with whole blood, a convenient procedure for the assessment of the riboflavin status in humans - Experientia 30: 665-667.
Grudniewska J., Dobosz S. 2007 - Use of Bronopol and Oxim treatments during incubations rainbow trout eggs - In: XII European Congress of Ichthyology, Book of abstract, 9-13 September 2007, Cavtat (Dubrovnik), Croatia: 92-93.

Grudniewska J., Terech-Majewska E., Góral C. 2008. - Evaluate the efficacy of the biocidal product in the hatchery during egg incubation and prophylactic bathing rainbow trout (Oncorhynchus mykiss) fry - In: Biotechnology in aquaculture (Eds) Z. Zakęś, J. Wolnicki, K. Demska-Zakęś, R. Kamiński, Wyd. IRS, Olsztyn: 395-401 (in Polish).

Grudniewska J., Terech-Majewska E., Kazuń B., Dyszkiewicz L., Olszewski A. 2007 - The use of acid biocidal product in the hatchery and rearing of salmonids - Komun. Ryb. 5: 11-15 (in Polish)

Halliwell B., Gutteridge J.M.C. 2007 - Free Radicals in Biology and Medicine, 4th Ed. - Oxford University Press, New York.

Hebert N., Gagné F., Cejka P., Bouchard B., Hausler R., Cyr D.G., Blaise C., Fournier M. 2008 - Effects of ozone, ultraviolet and peracetic acid disinfection of a primary-treated municipal effluent on the immune system of rainbow trout (Oncorhynchus mykiss) - Comp. Biochem. Physiol. C Toxicol. Pharmacol. 148: 122-127.

Jussila J., Makkonen J., Kokko H. 2011 - Peracetic acid (PAA) treatment is an effective disinfectant against crayfish plague (Aphanomyces astaci) spores in aquaculture Aquaculture 320: 37-42.

Kamyshnikov V.S. 2004 - Reference book on clinic and biochemical researches and laboratory diagnostics MEDpress-inform, Moscow (in Russian).

Kitis M. 2004 - Disinfection of wastewater with peracetic acid: a review - Environ. Int. 30: 47-55.

Koroliuk M.A., Ivanova L.I., Maiorova I.G., Tokarev V.E. 1988 - A method of determining catalase activity - Lab. Delo. 1: 16-19.

Kostiuk V.A., Potapovich A.I., Kovaleva Zh.V. 1990 - A simple and sensitive method of determination of superoxide dismutase activity based on the reaction of quercetin oxidation - Vopr. Med. Khim. 36: 88-91.

Levine R.L., Garland D., Oliver C.N., Amici A., Climent I., Lenz A.G., Ahn B.W., Shaltiel S., Stadtman E.R. 1990 Determination of carbonyl content in oxidatively modified proteins - Methods Enzymol. 186: 464-478.

Liberti L., Notarnicola M. 1999 - Advanced treatment and disinfection for municipal wastewater reuse in agriculture - Water Sci. Technol. 40: 235-245.

Mansell B., Powell M.D., Ernst I., Nowak B.F. 2005 - Effects of the gill monogenean Zeuxapta seriolae (Meserve, 1938) and treatment with hydrogen peroxide on pathophysiology of kingfish, Seriola lalandi Valenciennes, 1833 - J. Fish Dis. 28: 253-262. 
Marabini L., Frigerio S., Chiesara E., Radice S. 2006 - Toxicity evaluation of surface water treated with different disinfectants in HepG2 cells - Water Res. 40: 267-272.

Marjani A., Golalipour M.J., Gharravi A.M. 2010 - The effects of subacute exposure of peracetic acid on lipid peroxidation and hepatic enzymes in Wistar rats - Oman Med. J. 25: 256-260.

McAndrew K.J., Sommerville C., Wootten R., Bron J.E. 1998 - The effects of hydrogen peroxide treatment on different life-cycle stages of the salmon louse, Lepeophtheirus salmonis (Krøyer 1837) - J. Fish Dis. 21: 221-228.

Meister A. 1994 - The glutathione-ascorbic acid antioxidant systems in animal - J. Biol. Chem. 269: 9397-9400.

Moin V.M. 1986 - A simple and specific method for determining glutathione peroxidase activity in erythrocytes - Lab. Delo. 12: 724-727.

Picón-Camacho S.M., Marcos-Lopez M., Bron J.E., Shinn A.P. 2012 - An assessment of the use of drug and non-drug interventions in the treatment of Ichthyophthirius multifiliis Fouquet, 1876, a protozoan parasite of freshwater fish - Parasitology 139: 149-190.

Ross S.W., Dalton D.A., Kramer S., Christensen B.L. 2001 Physiological (antioxidant) responses of estuarine fishes to variability in dissolved oxygen - Comp. Biochem. Physiol. C Toxicol. Pharmacol. 130: 289-303.

Rudd T., Hopkinson L.M. 1989 - Comparison of disinfection techniques for sewage and sewage effluents - J. Inst. Water Environ. Manag. 3: 612-618.

Russo R., Curtis E.W., Yanong R.P. 2007 - Preliminary investigations of hydrogen peroxide treatment of selected ornamental fishes and efficacy against external bacteria and parasites in green swordtails - J. Aquat. Anim. Health 19: 121-127.

Santos C.X.C., Anilkumar N., Zhang M., Brewer A.C., Shah A.M. 2011 - Redox signaling in cardiac myocytes - Free Rad. Biol. Med. 50: 777-793.
Sies H. 1997 - Oxidative stress: oxidants and antioxidants Exp. Physiol. 82: 291-295.

Srikanth K., Pereira E., Duarte A.C., Ahmad I. 2013 Glutathione and its dependent enzymes' modulatory responses to toxic metals and metalloids in fish - a review - Environ. Sci. Pollut. Res. 20: 2133-2149.

Stone J. R., Yang S. 2006 - Hydrogen peroxide: a signaling messenger - Antioxid. Redox Signal. 8: 243-270.

Straus D.L., Meinelt T. 2009 - Acute toxicity of peracetic acid (PAA) formulations to Ichthyophthirius multifiliis theronts - Parasitol. Res. 104: 1237-1241.

Straus D.L., Meinelt T., Farmer B.D., Mitchell A.J. 2012 Peracetic acid is effective for controlling fungus on channel catfish eggs - J. Fish Dis. 35: 505-511.

Van der Oost R., Beyer J., Vermeulen N.P. 2003 - Fish bioaccumulation and biomarkers in environmental risk assessment: a review - Environ. Toxicol. Pharmacol. 13: 57-149.

Van Kuijk F.J.G.M., Sevanian A., Handelman G.J., Dratz E.A. 1987 - A new role for phosholipase A2: protection of membranes from lipid peroxidation damage - TIBS 12 : 31-34.

Wilhelm Filho D. 1996 - Fish antioxidant defenses - a comparative approach - Braz. J. Med. Biol. Res. 29: 1735-1742.

Wilhelm Filho D. 2007 - Reactive oxygen species, antioxidants and fish mitochondria - Front. Biosci. 12: 1229-1237.

Yim M.B., Chock P.B., Stadtman E.R. 1990 - Copper, zinc superoxide dismutase catalyzes hydroxyl radical production from hydrogen peroxide - Proc. Natl. Acad. Sci. USA 87: 5006-5010.

Yin X., Zheng Y., Liu Q., Cai J., Cai L. 2012 - Cardiac response to chronic intermittent hypoxia with a transition from adaptation to maladaptation: the role of hydrogen peroxide - Oxid. Med. Cell Longev. Article ID: 569520, doi: 10.1155/2012/569520.

Zar J.H. 1999 - Biostatistical Analysis - Prentice-Hall Inc., Englewood Cliffs, New Jersey. 